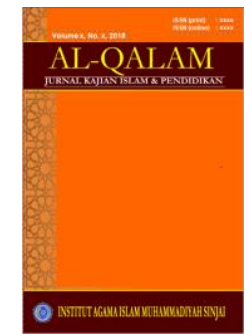

AL-QALAM

Jurnal Kajian Islam \& Pendidikan

Volume 7, No. 1, 2015

ISSN (print) : 1858-4152

ISSN (online) : 2715-5684

Homepage : http://journal.al-qalam.iaims.ac.id

\title{
PENDIDIKAN BERBASIS MASYARAKAT
}

\author{
Oleh: Hasmiati*
}

$* * * *$

\begin{abstract}
Abstrak
Pendidikan berbasis masyarakat merupakan perwujudan pendidikan melalui perluasan pelayanan pendidikan untuk kepentingan masyarakat. Pendidikan berbasis masyarakat menjadi sebuah gerakan penyadaran masyarakat untuk terus belajar sepanjang hayat dala mengatasi tantanan kehidupan yang beubah-ubah semakin berat. Secara konseptual model pendidikan berbasis masyarakat adalah model penyelenggaraan pendidikan yang bertumpu pada prinsip "dari masyarakat, oleh masyarakat dan untuk masyarakat" pendidikan dari masyarakat maksudnya pendidikan yang memberikan jawaban kebutuhan masyarakat. Pendidikan oleh masyarakat artinya masyarakat dapat diposisiskan sebagai penyelenggara pendidikan atau pelaku pendidikan itu sendiri, masyarakat diberikan kebebasan.
\end{abstract}

\section{Kata Kunci: Pendidikan dan Masyarakat}

\section{PENDAHULUAN}

Pendidikan adalah proses untuk memberikan manusia berbagai macam situasinyang bertujuanmemeberdayakan diri. Jadi banyak hal yang membicarakan pendidikan. Aspekaspek ayng bias dipertimbangkan antara lain; 1) Proses penyadaran; 2) Proses pencerahan; 3) Proses pemberdayaan; 4) Proses perubahan perilaku.

Berdasarkan konsep dan teori pendidikan maka dapat memberikan arti pendidikan yang berbeda. Aktivitas pendidikan sibuk membicarakan tentang apa dan bagaimana tindakan yang palaing efektif mengubah manusia agar terberdayakan, tercerahkan, tersadarkan dan menjadikan manusia sebagaiman mestinya manusia. ${ }^{1}$ Menganalisis konsep di atas sebagai referensi dalam mengembangkan dan mencari langkah-langkah yang harus ditempuh dalam mencapai tujuan pendidikan yakni memanusiakan manusia.

Pendidikan sebagai proses penyadaran merupakan strategis dalam melakukna proses pendewasaan manusia dengan melalui berbagai pendekatan agar tujuan pendidikan tersebut tercapai. Dalam mencapai tujuan penyadaran manusia maka banyak komponen atau tenaga pendidik harus terpenuhi dalam melakukan proses belajar mengajar. Tenaga pendidik

\footnotetext{
* Dosen Tetap STAI Muhammadiyah Sinjai

1. Soyomukti Nurani. Teori-teori Pendidikan: Jogyakarta.Ar-Ruz Media: 2010, hal. 34
} 


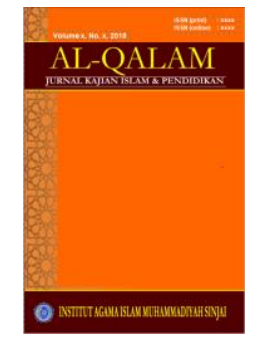

AL-QALAM

Jurnal Kajian Islam \& Pendidikan

Volume 7, No. 1, 2015

ISSN (print) : 1858-4152

ISSN (online) : 2715-5684

Homepage : http://journal.al-qalam.iaims.ac.id

tersebut diantaranya harus memiliki visi dan misi secara kolektif dan perangkat pembelajaran yang membelajarkan. Agar peserta didik dapat mencapai sebuah kesadaran atas kehidupan sekarang dan masa yang akan datang. Kesadaran manusia harus dibangun dari proses awal dengan memahami dan mengkuti proses dan aturan yang telah diterapkan. Sebenarnya dalam mencapai tujuan pendidikan sebagai penyadaran moral manusia. Penting mengetahui dan menyadari bahwa manusia itu hidup ada yang menciptakan dan ada tujuan hidup sesunggunhnya.

Manusia hidup ada tugas mulia dari sang Maha Pencipta. Dengan demikian menyadari atau tidak dapat diserahkan secara person untuk memahami atau mengakui bahwa manusia itu hidup ada batas waktu tertentu, dan masih ada alam kehidupan lain yang yang menanti.

Pendidikan sebagai wadah proses pencerahan, karena pada kodratnya manusia itu ingin mencapai hidup yang tercerahkan. Pencerahan yang dimaksud meliputi pencerahan hati, pencerahan pemikiran, pencerahan pencarian jati diri dan pencerahan membangun dan mencerdaskan kehidupan bangsa.

Pendidikan sebagai proses pemberdayaan manusia Karena dalam pendidikan banyak persoalan kehidupan yang dipelajari dan diajarkan. Pada umumnya munusia itu memiliki sifat kelemahan diri dan kebodohan. Kelemahan sebagi sifat dasar manusia itu muklat adanya karena keika manusia dilahirkan dipermukaan bumi dalam keadaan lemah tanpa kekuatan apa-apa dan tanpa membawa bekal, kecuali membawa potensi menangis. hal ini menjadi dasar manusia itu perlu diberdayakan dengan cara melalui proses pendidikan.

Kalau manusia sudah merasa cukup bahwa diri mereka sudah berdaya maka tanpa melalui pendidikan maka hal tersebut dapat dikategorikan sebagai ciri manusia yang memiliki sifat arogansi.manusia yang memiliki sifat tersebut maka hal itu belum memiliki jiwa dan kesadaran pada diri mereka.jika manusia tidak mengalami pendidikan dan tidakmau belajar maka kebodohan akan menghampirinya setiap saat dan tentu kebodohan itu dekat dengan kemiskinan dan kebodohan. Maka untuk mencegah kemiskinan dan kebodohan manusa perlu melalui proses pembelajar secara berjenjang agar manusia itu sendiri dapat mencapai pemberdayaan. Baik pemberdayaan ilmu pengetahua, agama, ekonomi, sosial kemasyarakatan dan politik.

Selanjutnya, pendidikan sebagai proses perubahan perilaku atau melalui proses pendidikan dengan terstruktur dan berjenjang maka memiliki tujuan memanusiakan manusia membentuk karakter baik tenaga pendidik maupun peserta didik. Akan tetapi, tidak semua masyarakat yang melakukan proses pendidikan mencapai tujuan pendidik yang membentuk karakter atau mngubah perilaku.tanpa melihat pada sisi jenis atau legalitas lembaga pendidikan. Apakah lembaga itu sekolah agama, sekolah umun dan kejuruan atau politik, ekonomi, pemerintahan. Maka tidak ada jaminan untuk sukses mencapai pendidika sebagia pembentuk perilaku.terkecuali diserahkan pada person peserta didika atau tenaga pendidik. Kesadaran dan perubahan sikap tidak boleh dipaksakan terkecuali pengakuan diri untuk 


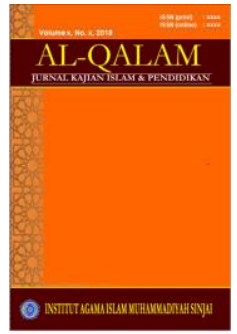

AL-QALAM

Jurnal Kajian Islam \& Pendidikan

Volume 7, No. 1, 2015

ISSN (print) : 1858-4152

ISSN (online) : 2715-5684

Homepage : http://journal.al-qalam.iaims.ac.id

berubah dan menyerahkan diri sepenuhnya kepada yang Maha memberi Rahmat dan Hidayah. Dengan dilandasi sebuah keikhlasan hakiki.

\section{PEMBAHASAN}

\section{A. Dasar Hukum Pendidikan Berbasis Masyarakat}

Dalam undang-undang Republik Indonesia npmor 20 tahun 2003 tentang sistem pendidikan nasional pada Bagian Kedua mengatur masalah Pendidikan Berbasis Masyarakat Pasal 55 ayat 1,2,3 dan ,4 yaitu: ayat : 1) Masyarakat berhak menyelenggarakan pendidikan berbasis masyarakat pada pendidikan formal dan nonformal sesuai dengan kekhasan agama, lingkungan sosial, dan budaya untuk kepentingan masyarakat. Merujuk pada undang-undang nomor 20 tahun 2003 tersebut pasal 55 ayat satu tersebut maka masyarakat memiliki haka mendirikan sebuah lembaga pendidikan yang berbasis masyarakat. Namun, jika dilihat pada konteks kehidupan sosial sangatlah kurang ada sekolah yang berbasis masyarakat yang sesuai dengan undang-undang tersebut karena masyarakat tidak mengetahui bagaimana caranya mendirikan sebuah lembaga pendidikan berbasis masyarakat. Baik berupa sekolah berbasis agama, sosial dan budaya lokal.

Meskipun Negara memberi kebebasan masyrakat berfartisifasi membangun sebuah lembaga sekaligus tujuan akhir mencerdaskan kehidupan bangsa, mencerdaskan anak bangsa. Selanjutnya pada ayat dua dapat kita simak berbunyi 2) Penyelenggara pendidikan berbasis masyarakat mengembangkan dan melaksanakan kurikulum dan evaluasi pendidikan, serta manajemen dan pendanaannya sesuai dengan standar nasional pendidikan. Makna dari pasal tersebut dapat dikemukakan bahwa penyelenggara pendidikan berbasis masyarakat diberikan tugas besar mengembangkan sekolah yang dibangun dan melaksanakan aktivitas belajar harus memiliki perencanaan atau kurikulum serta evaluasikeberhasilan peserta didik atau evaluasi pendidikan setiap akhir semester tahun berjalan.

Segala perencanaan pendidikan ynag memiliki tujuan akhir demi mencapai standar mutu pendidikan maka dari awal harus memiliki perencanaan yang matan dan sistematis serta proporsional dapatdipertanggungjawabkan. Akan tetapi, kesalahan besar jika penyelenggara pendidikan hanya berfokus pada satu sisi yaitu hanya memimpikan tujuan akhir sukses mencapai nilai akhir penididikan dari hasil evaluasi. Misalnya penyelenggara pendidikan berusaha keras melakukan pendampingan ujian akhir siswa bahkan tenaga pendidik mengambil peran membantu sisiwa mengerjakan soal ujian siswa agar dapat dipandang peserta didiknya mencapai peringkat nasional atau mencapai standar penilaian nasional namun mereka tidak memperhatikan dan memenuhi semua proses pendidikan itu berlangsung.

Dengan demikian, Pelaksanaan pendidikan yangd ipaksakan tanpa melihat dan menganalisis kesuksesan peserta didik dalam menikmati proses pendidikan. Ini salah satu contoh deskripsi pelenyelenggaraan pendidikan yang tidak bermutu karena pendidikan bermutu itu tentu saja lebih memperhatikan bagaiaman proses pendidikan itu berjalan dengan 


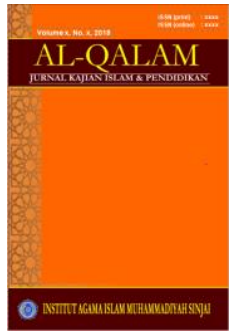

AL-QALAM

Jurnal Kajian Islam \& Pendidikan

Volume 7, No. 1, 2015

ISSN (print) : 1858-4152

ISSN (online) : 2715-5684

Homepage : http://journal.al-qalam.iaims.ac.id

baik dan memenuhi semua komponen penyelenggaraan pendidikan agar tidak ada yang dirugikan. Pada ayat ketiga undang-undang npmor 20 tahun 2003. Dana penyelenggaraan pendidikan berbasis masyarakat dapat bersumber dari penyelenggara, masyarakat, Pemerintah, Pemerintah Daerah dan/atau sumber lain yang tidak bertentangan dengan peraturan perundang-undangan yang berlaku.

Dari ayat tersebut, sangat jelas bahwa dana penyelenggaraan pendidikan bersumber dari penyelenggara pendidikan atau masyarakat itu sendiri yang membangun lembaga. Negara Indonesia yang begitu merdeka dan mengagungkan kemerdekaannya setiap tahun tetapi ika dilihat dari sisi kualitas pendidikan selalu saja dilemparkan kepada masyarakat, negeri ini besar tetapi sangat sedikit memperhatikan kualitas pendidikan dan bagaiamana mendanai pendidikan itu serta memperhatikan peningkatan kualitas tenaga pendidik.

Sebenarnya pendidikan itu bisa berkualitas dengan baik jika menempatkan tenaga profesional sesuai keahlian bidang studi masing-masing, tenaga pendidik tentu saja jika dianalis dari latr belakang pendidikan harus bidang ilmu yang ditekuni dan betul-betul dipelajari secara mendalam. Jangan menempatkan tenaga pendidikan hanya karena metode pendekatan kelauarga tanpa melihat latar belakang tenaga pendidik tersebut. Sebagai contoh Sekolah SMA A yang berada pada sebuah desa B. terdapat Guru agama yang latar belakang pendidikannya Paket C. tetapi S1 nya memang PAI.mengajar studi pendidikan Agama Islam pada kelas I SMA. Dalam proses mengajar menurut laporan siswa cara mengajar guru tidak professional dan berbeda dengan guru lainnya. Sehingga kadang membuat siswa ambigu. Dari kasus tersebut Tenaga pendidik mengajar SMA dia sendiri tidak pernah belajar pada tingka SMA. Sekiranya tenaga pendidik tersebut mengajar pada SMP. Maka boleh saja karena ia pernah mengalami proses pada tingkat sederajat sekolah yang ditempati mengajar.sehingga kulaitas pendidikan saat ini banyak yang dipertanyakan masyarakat. Saat ini anak sekolah tamatan SMA tidak seperti dulu. Jika berbicara pada perbandingan kualitas pendidikan SMa dahulu lebih Nampak keewasan cara berpikir dan beragamanya bila dibangdingkan dengan sekarang.

Kemudian ayat keempat pada pasal 55 ayat 4 yang berbunyi Lembaga pendidikan berbasis masyarakat dapat memperoleh bantuan teknis, subsidi dana, dan sumber daya lain secara adil dan merata dari Pemerintah dan/atau Pemerintah Daerah. Ketentuan mengenai peran serta masyarakat sebagaimana dimaksud dalam ayat (1), ayat (2), ayat (3), dan ayat (4) diatur lebih lanjut dengan Peraturan Pemerintah. Dari pemaknaan ayat tersebut sangat jelas bahwa lembaga atausekolah pendidikan yang berbasismasyarakat dpat memeproleh bantuan teknis, subsidi dana dan smuber daya lain.

Jika kita melihat realita yang terjadi bahwa pendidikan yang berbasis masyarakat sangat jelas landasan hukumnya akan tetapmasyarakat tidakpaham karena pemerintah tidak terbuka melakukan sosialisasi tentang kebebasan masyarakat mendirikan sekolah yang berbasis masyarakat karena pandangan masyarakat sangat sulit mendirikan seklah dan sangat susah jika mengurus perisinan pendirian sekolah. Untuk mendirikan sekolah butuh dana yang besar, 


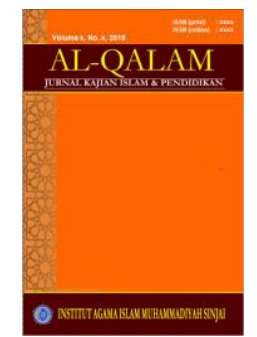

AL-QALAM

Jurnal Kajian Islam \& Pendidikan

Volume 7, No. 1, 2015

ISSN (print) : 1858-4152

ISSN (online) : 2715-5684

Homepage : http://journal.al-qalam.iaims.ac.id

meskipun sarjan latar belakang sarjana keguruan yang banyak menganggur karena mereka hanya berharap mau berpartisifasi pada sekolah identitasnya negeri.

\section{B. Konsep Pendidikan Berbasis Masyarakat}

Pendidikan berbasis masyarakat merupakan perwujudan pendidikan melalui perluasan pelayanan pendidikan untuk kepentingan masyarakat. Pendidikan berbasis masyarakat menjadi sebuah gerakan penyadaran masyarakat untuk terus belajar sepanjang hayat dala mengatasi tantanan kehidupan yang beubah-ubah semakin berat.

Secara konseptual model pendidikan berbasis masyarakat adalah model penyelenggaraan pendidikan yang bertumpu pada prinsip "dari masyarakat, oleh masyarakat dan untuk masyarakat" pendidikan dari masyarakat maksudnya pendidikan yang memberikan jawaban kebutuhan masyarakat. Pendidikan oleh masyarakat artinya masyarakat dapat diposisiskan sebagai penyelenggara pendidikan atau pelaku pendidikan itu sendiri, masyarakat diberikan kebebasan.

menyelenggarakan pendidikan dan sebagai pelaku utama pelaksanaan pendidikan secara bersama-sama Karena pada akhirnya keberhasilan dari tujuan pendidikan berbasisi masyarakat akan kembali pada kepentingan masyarakat, yakni membangun kepentingan masyarakat. Selain itu, masyarakat memiliki hubungan erat antara pendidikan dengan masyarakat. Pendidikan tanpa masyarakat maka tidak akan terjadi proses pendidikan karena masyarakatlah ynag mengisi pendidikan tersebut. Demikia jga dengan pendidikan. Masyarakat tanpa pendidikan maka tidak akan terjadi ada disebut proses pendidikan.jadi keduanya tidak bisa dipisahkan satu sama lain.akan tetapi pendidikan sebagai sentral pencerahan dan perubahan sosial.

\section{Masyarakat sebagai Tenaga Pendidik Profesional}

Tenaga kependidikan merupkan salah satu komponen pendidikan yang lahir dari masyarakat yang kesehariannya mendidik peserta didik atau anak bangsa atau dengan istilah umum disebut Guru. Sebagai Guru bertanggungjawab melakukan pencerahan pada anak didik mereka. Keberhasilan suatu bangsa msangat ditentkan oleh peran guru dalam pembangunan sebagai guru yang melakukan pemberdayaan dan pengembangan sumber daya manusia (SDM). Guru dapat dikatakan masyarakat terdidik dan professional. Diakui atau tidak, itu yang terjadi. Karena Guru adalah masyarakat pemikir dan pelaku perubahan.

Guru lahir semenjak ada manusia yang lahirdipermukaan bumi, karena begitu guru ada dalam kehidupan. Guru sebagi tenaga professional dalam bidang mengajar, berbicara professional merupakan kegitan yang dilakukan oleh seseorang dan menjadi sumber penghasilan kehidupan yang memerlukan keahlian, kemahiran dan kecakapan yang 


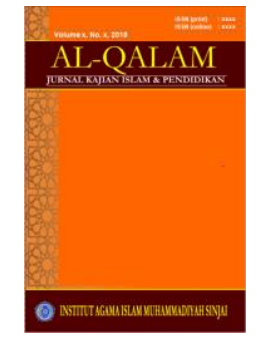

AL-QALAM

Jurnal Kajian Islam \& Pendidikan

Volume 7, No. 1, 2015

ISSN (print) : 1858-4152

ISSN (online) : 2715-5684

Homepage : http://journal.al-qalam.iaims.ac.id

memenuhi standar mutu atau norma tertentu dan memerlukan pendidikan profesi ( UndangUndang Nomor 14 tentang Guru dan Dosen). ${ }^{2}$

Profesi menunjukkan lapangan yang khusus dan mensyaratkan studi dan penguasaan pengetahuan khusus yang mendalam, seperti bidang hukum, bidang pendidikan, bidang militer, bidang tekhnologi dan informasi serta bidang agama dll.

Pekerjaan yang bersifat professional adalah pekerjaan yang hanya dapat dilakukan oleh mereka yang khusus dipersiapkan untuk itu dan bukan pekerjaan yang dialkukan oleh mereka kareitu dapat memperoleh pekerjaan yang lain.

Suatu pekerjaan professional memerluknan persyaratan khusus, yakni 1). Menunut adanya keterampilan berdasarkan konsep dan teori ilmu pengetahuan yang mendalam. 2). Menekankan pada suatu keahlian dalam bidang tertentu sesuai dengan bidang profesinya. 3). Menuntut adanya tingkat pendidikan yang memadai. 4) adanya kepekaan terhadap dampak kemasyarakatan dari pekerjaan yang dilaksanakannya5).memungkinkan perkembangan sejalan dengan dinamika kehidupan. ${ }^{3}$

\section{Kinerja Tenaga Kepandidikan}

Produktivitas individu dapat dinilai dari apa yang dilakukan oleh individu tersebut dalam kerjanya, yakni bagaiaman ia melakukanpekerjaan atau untuk dikerjanya. Dalam hal ini, produktivitas dapat ditinajau berdasarkan tingkatannya dengatolok ukur masing-masing, yangdapat dilihat dari kinerjanya tenaga kependidikan. Kinerja atau performasi dapatdiartikan sebagi prestasi kerja, pelaksanaan kerja, pencapaian kerja, hasil kerja atau untukkerja. Sejalan dengan itu, Smith, menyatakan bahwa kinerja adalah " out put drive from processes, human or otherwise", jadi kinerjanya merupakan hasil atau keluaran dari suatu proses. $^{4}$

\section{E. Pemberdayaan Masyarakat Sipil melalui Pendidikan}

Dalam rangka mencapai tujuan pendididkan yakni mencerdaskan kehidupan bangsa maka perlu mengagendakan program pendidikan pemerdayaan masyarakat. Dalam program tesebut masyarakat sangat dibutuhkan partisifasinya dan masukan demi memajukan pendidikan yang bermutu. Di sisi alain masyarakat memerlukan jasa sekolah untuk mendapatkan programprogram pendidikan sesuai dengan diinginkan. Jalinan semacam ini dapat terjadi. Sekolah sangat dibutuhkan dalam hubungan pembangunan suatu bangsa karena masyarkat perlu paham tentang kesadaran tentang pentingnya pendidikan menata masa depan kehidupan ayng mencerahkan dan memberdayakan.

\footnotetext{
${ }^{2}$ Kunandar, Guru profesional : jakarta. Pt raja grafindo persada: 2007., hal. 55

3 . Kunandar, Guru Profesional : Jakarta. PT Raja grafindo Persada. 2007. Hal. 79

${ }^{4}$ Mulyasa.E..Menjadi Kepala Sekoah Professional : Bandung. PT. Remaja Rosdakarya: 2009, hal. 98
} 


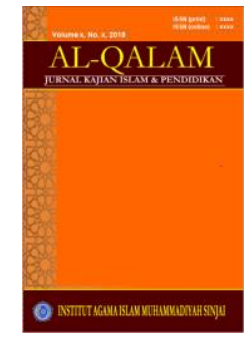

AL-QALAM

Jurnal Kajian Islam \& Pendidikan

Volume 7, No. 1, 2015

ISSN (print) : 1858-4152

ISSN (online) : 2715-5684

Homepage : http://journal.al-qalam.iaims.ac.id

Dalam pemberdayaan masyarakat dan lingkungan sekolah maka perlu menggali secara bersama hal-hal yang menjadi pokok persoalan yang berkaitan dengan program yang akan mendukung keberhasilan pendidikan di masyarakat. Dalam pemeberdayaan masyarakat maka banyak hal yang menjadi perhatian khusus dalam mengembangkan potensi diri manusia agar mamu menciptakan sesuatu yang dianggap mampu membantu dan meringankan kebutuhan hidup melalui ilmu pengetahuan dan teknologi. Segala pengelaman dan pengetahuan masyarakat bisa digalih secara bersama supaya potensi dalam diri masyarakatberguna bagi nusa dan bangsa yakni masyarakat pemikir, partisifatif dan produktif.

\section{F. Tujuan Pendidikan di Masyarakat}

Kehidupan dalam masyarakat saat ini sangat dipengeruhi oleh paham modernisasi yang berkembng dimasyarakat sehingga kelangsungan hidup masyarakat kadang terbawa arus globalisi, terutama mengenai karakter, ekonomi bahkan paham itu sendiri yang selama ini menganut paham tradisional dan melestarikan budaya dan tradisi yang berlangsung. Kebudayaan menjadi objek dan sasaran globalisasi, sangat jarang lagi ada sosial buday yang bebas dari pengeruh paham kapitalisme, konsumerisme, materialism dan lain-lain.

Selanjutnya, kehidupan masyarakat direa modern dengan menglobalnya budaya yang tak ada sekat secar tidak langsung menciptakan batas-batas moralitaskehidupan semaki tipis. Misalnya, agama sejak dating dijadikan sebagai pegangan hidup umat manusia segala prinsip-prinsip kehidupan yang berupa pola tingka laku di masyarakat, tradisi menghargai orang lain dengan cara berpakaian sopan dan menutup aurat, sikap saling tolong menolong sesame, menghargai perbedaan dan sebaginya saat init eras terasing seirig kemajuan dan pengaruh modernisasi yang perlahan-lahan menciderai moralitas manusia yang mulia itu. ${ }^{5}$

\section{DAFTAR PUSTAKA}

Kunandar, 2007. Guru Profesional : Jakarta. PT Raja Grafindo Persada.

Mahfud Chairul,2009. Pendidikan Multikultural: Yogyakarta. Pustaka Pelajar.

Mulyasa.E.2009.Menjadi Kepala Sekoah Professional : Bandung. PT. Remaja Rosdakarya

Rembagy Musthofa, 2010. Pendidikan Transformatif: Yoyakarta. Teras

Zubaedi, 2009. Pendidikan Berbasis Masyarakat: Yoyakarta. Pustaka Pelajar.

${ }^{5}$. Rembagy Musthofa, Pendidikan Transformatif : Yoyakarta. Teras; 2010. Hal. 112 